admit one finger) and those in which the stenosis was less severe than this. There were 36 cases of the former class and 34 of the latter. In 15 cases of the severe form of stenosis there was hypertrophy of the walls of the left auricle with no dilatation of its cavity, in 11 there was hypertrophy with dilatation, in three dilatation alone was recorded, and in seven there was no note made as to the condition of the left auricle. Hypeitrophy, therefore, was found in 26 and dilatation in 14 of the cases. Of these 70 cases, 18 came from the surgical wards and in only one of these was dilatation recorded and in this case was associated with bypertrophy of the walls of the auricle. There is therefore considerable post-mortem evidence that hypertrophy of the walls of the left auricle occurs in this valvular lesion.

Again, Dr. T. D. Acland" says: "In cases of mitral obstruction, in which the auricle might be supposed to have extra active work thrown upon it, hypertrophy is more marked than in simple regurgitation." Cardiographic tracings of patients suffering from mitral stenosis also indicate that the left auricle is considerably hypertropied, since these records show an abnormal magnitude of the elevation caused by the auricular systole. The auricular systole is sometimes so exaggerated as to be sufficiently powerful to thrust the heart forwards against the chest wall, and so to make the cardiac impulse commence before the ventricular systole. When compensation begins to fail the elevation caused by the auricular systole becomes greatly diminished and may even disappear. The evidence therefore is in favour of the view that the walls of the left auricle are usually hypertrophied and that its cavity is not dilated or only to a slight extent. The question which naturally presents itself is, Why does hypertrophy of the walls of the left auricle, with very little dilatation of its chamber, occur in mitral stenosis when in mitral regurgitation there are generally a considerable amount of dilatation and only slight hypertrophy?

In mitral stenosis as the left auriculo-ventricular orifice becomes diminished in size the increased strain is chiefly felt by the left auricle during its own systole, since during its diastole the blood is being drawn through the mitral opening by the suction action of the dilating left ventricle. The time occupied by the auricular systole corresponds to about one-tenth of the whole of the cardiac cycle, although when there is mitral obstruction this period is undoubtedly lengthened. It is only during this short period in each cardiac cycle that there is thrown upon the walls of the left auricle an increased strain, which is caused by the greater force required to drive the blood through the narrowed mitral orifice. In consequence the muscular tissue has time to adapt itself by undergoing hypertrophy, since the extra amount of work it is called upon to perform is only gradu. ally increased and only exists for a short period during each cardiac cycle. In mitral incompetency, on the other hand, some blood is regurgitated during nearly the whole time occupied by the ventricular systole, so that the strain on the left auricle is more suddenly increased and continues over a longer period of the cardiac cycle than is the case in the former condition. This might cause some bypertrophy of the left auricular walls, but it is obvious that the conditions are not nearly so farourable for this protective change to take place as they are in mitral stenosis. The chamber of the left auricle will tend to become dilated as it has to con. tain the regurgitated blood from the left ventricle as well as that entering from the pulmonary veins. It is necessary in mitral regurgitation for the left auricular chamber to be larger than in health, in order that it may hold the increased amount of blood which is poured into it from these two sources during the ventricular systole. In mitral stenosis the increased strain is thrown on the left auricle during its systole, whereas in mitral regurgitation it is placed upon it during its diastole, and "it is a generally recognised fact that a very effective canse in producing dilatation of the cavities of the heart is undue distension during diastole, and that if nutrition is well maintained obstruction during systole tends rather to cause hypertrophy." "The result is that the walls of the left auricle tend to become hypertrophied in mitral stenosis, whereas in mitral regurgitation the tendency is for the cavity of the auricle to become dilated.

The changes which occur in the right side of the heart must not be forgotten, since very early in mitral stenosis there is hypertrophy of the right ventricular walls, so that at the end of the ventricular systole the left auricle would

5 Aclanrl: The Lancet, July 20th, 1889, p. 103.

6 Acland: loc. cit. probably contain more blood than in health. As a result of this hypertrophy there is some tendency for the left auricle to become distended; but the distension would not be nearly so great as in mitral regurgitation, and the increased strain would quickly be reduced by the diastole of the ventricles. With a hypertrophied condition of the walls of the left auricle there will not be so much strain thrown on the right side of the heart as there would be if the cavity of the left auricle was distended and the power of its contractions was diminished. The smaller the chamber of the left auricle the greater power has its contracting walls to drive the blood onwards. This has been pointed out by Mr. Robert $H$. Woods ${ }^{\top}$ who has shown that "the blood pressure inside a contracting cardiac chamber varies inversely as the radius of the chamber," and that "if the increasing thickness of the contracting walls be also taken into consideration the blood pressure must finally increase inversely as the cube of the radius."

From these considerations it would appear that the left auricle is placed in much better circumstances to deal with the impeded flow of blood through the heart in mitral stenosis than it is in mitral regurgitation. The result of this compensatory hypertrophy of the left auricle in mitral stenosis is that the other chambers of the heart do not become so early dilated as in mitral regurgitation, and the cardiac dropsy, which so easily appears in the latter valvular lesion, does not present itself until latte in the disease. We may conclude, therefore, that hypertrophy of the walls of the left auricle is the chief factor in maintaining cardiac com. pensation in mitral stenosis, and that it is only after the auricle has begun to fail, which does not occur until late in the course of the disease, that the right ventricle and auricle dilate and dropsy supervenes.

$$
\text { I am, Sirs, yours faithfully, }
$$

JAMES E. H. SAWYeR, M.A., M.D. Ozon., late house physician at St. Thomas's Hospital and at the Bethlem Royal Hospital, London.

\section{MALIGNANT GROWTHS AND NORMAL REPRODUCTIVE TISSUES.}

\section{To the Editors of THW LANCET.}

SIRS, -We were greatly interested to learn from the letter appearing in THE LANCET of Jan. 2nd under the above title that Dr. G. T. Beatson had as long ago as 1896 put forward the view "that the active processes seen in a cancerous tumour are best explained by regarding the epithelium of the part as having taken on the properties and powers of germinal epithelium." Though with our present knowledge the term "germinal epithelium" can hardly be applied to cells which are destined immediately to undergo, or have undergone, a reduction division, to which we have applied the terms "gametogenic" and "gametoid," the former to those occurring normally, the latter to those whose presence is abnormal, it would have been difficult at the time he wrote for Dr. Beatson to have come nearer to the facts since demonstrated by us. There are, however, a few points with regard to our paper to the Royal Society which this letter leads us to believe would be elucidated by a brief explanation.

While there is a vague similarity in many respects between the general idea suggested by Dr. Beatson and those conclusions which we have drawn from our definite cytological investigations of malignant growths, we must state that we differ from him in many important details which space will not at present allow us to discuss. We would, however, draw attention to the following points. The chief conclusion drawn by Dr. Beatson from his clinical observations was, as far as we are able to make out from a careful perusal of his original paper, that the ovaries and testicles exercise "a control in the human body over local proliferations of epithelium" and that "the removal of the tubes and ovaries has an effect upon the local proliferation of epithelium which occurs in carcinoma of the mamma." To these conclusions he was led by his clinical observations of several cases, particularly of one of carcinoma of the breast where he removed the ovaries and tubes of the patient. In this case the carcinoma was apparently cured, Dr. Beatson attribut'ng the cure to

Woods: Journal of Anatomy and Physiology, vol xxvi. Quoted from Dr. D. W. Samways, Brit. Med. Jour., January, 1897, p. 200. 
the removal of the ovaries. Our observations upon malignant growths have, on the other hand, been entirely microscopical and we have simply described what we have seen and are able to demonstrate. We express no opinion, one way or the other, as to the possible influence of the ovary or testicle upon the production or growth of malignant tumours.

We would lay particular stress upon the fact that we have shown that cells which hare been for a long time carrying out specialised somatic functions may, under certain conditions, become gametogenic and go through a reduction division. In certain plants this occurs normally. In mammalia certain cells in the genital organs are set apart at some period during the life of the organism to produce sexual germ cells, and in these at the proper time reduction takes place normally. When, however, reduction division takes place in other somatic cells abnormally the growth possesses not only a parasitic character but is also malignant. This reduction division may apparently take place anywhere and in any kind of tissue and the presence of such cells enables us to differentiate between benign and malignant growths. With regard to Dr. Beatson not being sure about our statement as to the exact mode of development of normal gametogenic cells, we would merely point out that the features of this particular metamorphosis are matters of common knowledge among cytologists. - We are, Sirs, yours faithfully,

J. B. FARMER.

J. F, S. MOORE.

ChaRLES WALKer.

Royal Collegef Science, London, Jan. 11th, 1904.

\section{SPIRAL FORMATIONS IN RELATION TO WALKING, SWIMMING, AND FLYING. \\ To the Editors of THE LANCET.}

SIRs,-Never have I had the privilege of reading so interesting a study of spiral formations as that contributed by Professor J. Bell Pettigrew to THE LANCET of Jan. 2nd. I speak with natural diffidence in the matter, but with the exception of some papers by Dr. George Wherry on similar subjects I can recall no other publications that deal with spirals in the same way, and the honour done me by the mention of my name in your columns leads me to congratulate myself not only on having directed Professor Pettigrew's attention to the publication of a combined form of research which others have lamentably neglected but also on the value to the second edition of "Spirals in Nature and Art" of many new materials thus placed within my reach. How much more I should have appreciated so illuminating an article a little earlier I need scarcely say, and if Professor Pettigrew had only had an opportunity of reading my preliminary notes on this subject in their original form I should have been only too glad to embody in my first edition those corrections which would have so much improved it, especially in the case of the two diagrams, the correct authorship of which I acknowledged last July both in Nature and the Athenceum.

It is unexpected news both to my readers and myself that "the great interest taken in artificial flight of late years ...... has been heightened by the publication (1903) of a small work" which has special reference to the architecture of an open staircase in Touraine. In that little book, I must repeat, the subject of flight was only a side issue and the name of Professor Pettigrew is mentioned with all the respect it deserves in connexion with the beautiful spiral fibres of the ventricle of the heart. But his article in THE LANCET of Jan. 2nd compels. me to inform you that I knew nothing more about him or his researches into flight until last June. This may seem stranger to him than it does to those who have been willing to accept me merely as a modest inquirer into various subjects of general interest which scientific specialists seem far too much inclined to keep to themselves, or to conceal in literature apparently written for a select audience and certainly published on a scale by no means commensurate with its importance.

Professor Pettigrew says, that "in none of Leonardo's manuscripts and in none of his figures is the slightest hint given of his having any knowledge of the spiral movements made by the wings in flight." That anyone of the scientific accuracy of Professor Pettigrew should thus be in a position involving complete knowledge of all Leonardo wrote or drew is a revelation which every lover of art and science will warmly welrome. I have only about 500 photcgraphs, in my own possession, of Leonardo's original MSS. on many various subjects; and I have only seen in many cities of Europe those MSS. hitherto known to be in existence. I recognise with pleasure that Professor Pettigrew must have larger sources on which to base his general statement. Of course, he does not solely depend on the one MS. he quotes. Yet even as to this Ms. alone I venture to adhere to my original opinion, basing it on general considerations of the translation of the Italian dialect and of the value of evidence with which $I$ am not wholly unacquainted. Leonardo's ideas of flight may not be those of Professor Pettigrew, yet I must respectfully, but finally, refuse to accept the Professor's conclusions as to Leonardo's omissions.

Professor Pettigrew need be under no apprehension that either his own scientific reputation or that of Fngland in the nineteenth century will be lessened by my remarks on Leonardo's manuscripts. He does me too much honour. It seems scr.rcely likely, to take a parallel instance, that anyone will think less of Lyell if I point out that Leonardo calculated a period of 200,000 years for the accumulations at the mouth of the Po and explained the meaning of the strata in the Apennines revealed by the cutting of the river Lamona. English scholars have naturally made a great advance on the investigations of Leonardo in botany, hydraulics, anatomy, morphology, astronomy, optics, and fight. But though the discovery of Leonardo's manuscripts has proved that several of their results were anticipated by the Italian I cannot believe that the reputation of our countrymen has been thereby diminished, even if patriotism were a serious consideration in scientific or artistic questions. It is the recognition im. plied, not only of the bond between various special forms of science, but also of the general interest involved in each department of it, which leads me to welcome so warmly the publication in your columns of Professor Pettigrew's valnable collection of examples of spiral formations, the forerunner, I hope, of many others from the same able pen. I should not be alone, for instance, in welcoming some description of the advance in our knowledge of the conchoid curve since Albrecht Dïrer, or of the new conceptions of phyllotaxis introduced by Mr. A. H. Church to supersede the theory of Bonnet and the mathematics of Calandrini. I venture on these suggestions because it seems to me that by such publications as that of Jan. 2nd you advance once more the ideal which has so often animated your pages and which I could wish were more widely appreciated elsewhere-I mean the ideal of bringing the results of modern scientific research before the notice of the public in a form which should prove not only advantageous to the general wellbeing but also conducive to the larger amenities of life.

Jan. 7th, 1904.

I am, Sirs, yours faithfully,

THEODORE A. COOK.

\section{THE BORDERLANDS OF INFECTIOUS DISEASES AND THEIR MANAGEMENT. \\ To the Editors of THA LANOET.}

SIRS, - This controversy has tended to bifurcate and there are now two distinct points at issue-the soundness of my original contention and the value of isolation hospitals. As to the former, I find myself engaged with Dr. Clement Dukes and Dr. E. W. Goodall, both of whom I must thank for their help in elucidating what may have been obscure in my former communications. May I reply to Dr. Dukes under the categorical heads that $r$ suggested and that he has kindly followed?

1. Here we have an assertion and a metaphor. I will not do Dr. Dukes the injustice of taking his parable of the wheat and the soil as an argument from analogy; that he surely cannot have intended. But I freely adopt his metaphor. An agriculturist goes forth to sow. He takes wheat (bacteria) and sprinkles it on soil (potential patients). The wheat germinates and produces, not wheat after its kind (bacteria), but something else (diseases)! Is this breeding true? I have accepted the metaphor. I claim that the wheat shall produce wheat, bacteria produce bacteria. Where does the disease come in? I follow the metaphor. The wheat in its growth produces certain changes in the zoil; the bacteria in their growth produce certain 